\title{
Food Behavior of Pupils in the City of Bobo-Dioulasso (Burkina Faso)
}

\author{
Téné Marceline Yaméogo ${ }^{1,2^{*}}$, Bazoumana Coulibali1, Aimée Senkaye-Lagom Kissou1,2, \\ Issiaka Sombié1, Carole Gilberte Kyelem ${ }^{1,2}$, Mireille Marie D. Tapsoba ${ }^{1}$, Alassane Ilboudo², \\ Omar Guira3 ${ }^{3}$, Djingri Lankoandé2, Abraham Bagbila², Marina Birba², \\ Macaire Sampawindé Ouédraogo ${ }^{1,2}$, Youssouf Joseph Drabo ${ }^{3}$
}

${ }^{1}$ INSSA, University Nazi Boni, Bobo-Dioulasso, Burkina Faso

${ }^{2} \mathrm{CHU}$ Souro Sanon, Bobo-Dioulasso, Burkina Faso

${ }^{3}$ UFR-SDS, University Joseph Ki Zerbo, Ouagadougou, Burkina Faso

Email: *teneline@gmail.com

How to cite this paper: Yaméogo, T.M., Coulibali, B., Kissou, A.S.-L., Sombié, I., Kyelem, C.G., Tapsoba, M.M.D., Ilboudo, A., Guira, O., Lankoandé, D., Bagbila, A., Birba, M., Ouédraogo, M.S. and Drabo, Y.J. (2018) Food Behavior of Pupils in the City of Bobo-Dioulasso (Burkina Faso). Open Journal of Pediatrics, 8, 134-140.

https://doi.org/10.4236/ojped.2018.82016

Received: April 15, 2018

Accepted: May 11, 2018

Published: May 14, 2018

Copyright $(9) 2018$ by authors and Scientific Research Publishing Inc. This work is licensed under the Creative Commons Attribution International License (CC BY 4.0).

http://creativecommons.org/licenses/by/4.0/

\begin{abstract}
Introduction: Diet is a determinant of chronic non transmissible diseases. The aim of this study was to describe pupils' diet in the city of Bobo-Dioulasso (Burkina Faso). Methods: This was a descriptive cross-sectional study that took place from March to April 2016, among 1st, 4th and 7th form pupils of public and private schools in the city of Bobo-Dioulasso. Diet survey methods were a reminder of the last 24 hours and the questionnaire of consumption frequency. Results: A total of 1993 pupils were surveyed. The mean age was $17.5 \pm 3.6$ years and the sex ratio 0.7. The majority of pupils (90.5\%) reported eating at least 3 meals a day. Dietary recommendations were different according to food groups. For example, vegetables (90.0\%), fruits (75.4\%) and dairy products (79.3\%) were the least well consumed foods compared to recommendations. Protein and starch intake were inadequate among these pupils with $39.7 \%$ and $58.2 \%$ respectively. Almost $1 / 4$ had a regular weekly alcohol consumption (23.4\%) while an excessive consumption of sweet drinks and fried foods was noted in $12.7 \%$ and $28.2 \%$ of them, respectively. Conclusion: This study has revealed a general insufficiency in the recommended dietary intakes of fruit, vegetables, proteins, starchy foods and dairy products among pupils, and on the other hand, a regular consumption of fatty, sugary and alcoholic foods for about a fifth of them. An intervention program such as "Communication for Continuous Behavior Change" would help improve these habits.
\end{abstract}

\section{Keywords}

Food Behavior, Pupils, Burkina Faso 


\section{Introduction}

Apart from hypertension, obesity, hyperglycemia, dyslipidemia, sedentary lifestyle and smoking, food behaviors such as the low consumption of fruits and vegetables, the excessive consumption of alcoholic beverages are currently recognized as cardiovascular risk factors through nontransmissible diseases (NTDs) [1].

According to WHO, by eliminating modifiable risk factors including harmful eating habits, we would prevent $80 \%$ of premature heart disease, $80 \%$ of premature brain strokes, $80 \%$ of type 2 diabetes, and $40 \%$ of cancers. Children are not exempt from this problem. Overweight, obesity and type 2 diabetes are becoming more common among children and adolescents [2].

The determinants of food behavior are known and are of two kinds: individual determinants (age, sex, food preferences, and knowledge) and collective determinants (economic, social and physical environments) [3].

In the United States, studies have shown a deterioration in the quality of the diet and a decline in the frequency of lunch with age, as well as an increase in snacks among pupils; while children who have lunch regularly tend to have a better diet than those who do not [4] [5].

In order to reduce the effects of major risk factors such as unhealthy diet and lack of physical exercise, the World Health Assembly adopted in May 2004 the "Global Strategy for Food, Physical Exercise and Health" (DPAS).

Among other measures, the DPAS calls on Member States to develop and implement school policies and programs to promote healthy diet and increase the practice of physical exercise [2].

The general characteristics of secondary school pupils' food habits are more or less known in Burkina Faso, and particularly in Bobo-Dioulasso region. In Ouagadougou, Daboné in 2011, in a study including 799 middle class schoolchildren (mean age: $11.7 \pm 1.4$ years) reported that during the week preceding the study, $25 \%$ of children had not eaten fruit, $20 \%$ no meat, $20 \%$ no vegetables while $18.3 \%$ consumed ice cream every day [6].

Our study aims to lay the basis for a reflection on the appropriate cardiovascular prevention measures for this category of our population, the adolescents.

\section{Methods}

This was a cross-sectional study that took place from March to April 2016, among 1st, 4th and 7th form pupils of public and private schools in the city of Bobo-Dioulasso. The calculation parameters of the sample were as follows: prevalence $8 \%$ (prevalence of overweight/obesity at school in Burkina [7], accuracy $3 \%$, alpha error $5 \%$ ( $95 \% \mathrm{CI}), \mathrm{N}=65765$ pupils, a cluster effect 2 . The calculated sample was 1890 pupils, distributed to 630 pupils per class group of 1st, 4th and 7 th form in order to detect a possible gradient according to the level of studies.

Food survey methods consisted in a reminder of the last 24 hours associated with consumption frequency questionnaire. The questionnaire was self-administered, 
under the supervision of intern medical students.

In order to better profile possible future prevention actions, we have highlighted in the results, the behaviors that deviate from the usual dietary recommendations. Thus, we have defined as non-recommended diet, the consumption of:

- more than 3 sweet drinks (soda) or sweetened juice per day $(33 \mathrm{cl} \times 3)$;

- less than 1 serving of vegetables per day;

- less than 1 fruit per day;

- less than 1 dairy product per day;

- less than one serving of protein per day;

- less than 3 rations of starchy foods per day;

- more than one ration of food fried/cooked in oil per day;

- more than 1 alcoholic beverage per week.

The overall project of this study was approved by the Burkina Faso National Ethics Committee. Authorizations from the Regional Director of Secondary Education and Secondary Schools Administration were obtained for the survey. An informed consent form attached to an information leaflet was sent to parents before the survey. Only pupils whose parents gave their consent by signing the consent form were interviewed. The data was also processed respecting the anonymity of respondents.

\section{Results}

A total of 1993 pupils, distributed as follows, were interviewed: 649 in 1st form, 673 in 4 th form and 671 and 7 th form.

\subsection{General Characteristics of Pupils}

The mean age of the pupils was $17.5 \pm 3.6$. The mean age per class group was $13.6 \pm 1.5$ years in the 1 st form, $17.5 \pm 1.8$ years in the 4 th form, and $21.3 \pm 2.0$ years in the 7th form.

Female pupils accounted for $56.6 \%(\mathrm{n}=1128)$, that is a sex ratio of 0.8 .

The majority of students were single: $99.1 \%(\mathrm{n}=1976)$. The remaining $0.9 \%$ $(\mathrm{n}=19)$ were married or cohabiting. Two-thirds of them lived with their two parents $(67.6 \%), 15.3 \%$ with only one parent and $17.0 \%$ with another member of the family.

The occupations of fathers/guardians were mainly: farmers $25.4 \%$ of the cases, traders $23.4 \%$ and civil servants $21.4 \%$. The occupations of mothers/tutors were: housewives $48.8 \%$ and traders $27.9 \%$.

The body mass index was found to be overweight for $7.3 \%(n=146)$ of pupils with $1.4 \%$ of obese subjects and leanness for $16.8 \%(n=366)$.

\subsection{Diet}

\subsubsection{Number of Daily Meals}

The majority (90.5\%) had 3 meals or more per day (Figure 1). 


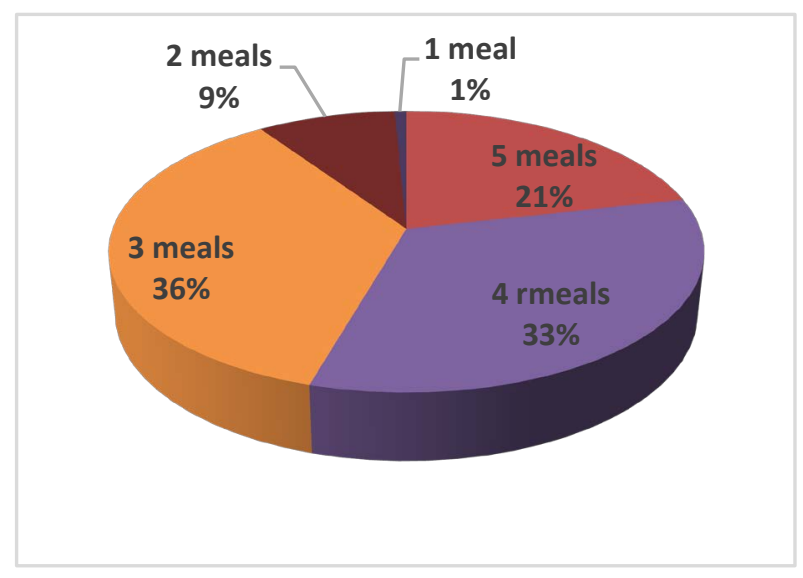

Figure 1. Number of pupils' daily meals in Bobo-Dioulasso (Burkina Faso), 2016.

One-fifth of the pupils, $21.5 \%(\mathrm{n}=428)$, had 5 meals/day (a breakfast, a lunch, a snack at 10 am and $4 \mathrm{pm}$ and a dinner). It was mostly:

- girls: $23.1 \%$ against $19.3 \%$ of boys $(\mathrm{p}=0.03)$;

- $\quad$ st form and 4th form pupils: $29.6 \%$ and $23.0 \%$ against $12.0 \%$ for 7 th form pupils ( $\mathrm{p}<0.001)$;

- under 15 years: $32.0 \%$ against $18.1 \%$ for those aged 15 years and over $(\mathrm{p}<$ 0.001).

The participation of pupils in the different meals of the day was greater at lunch and dinner, respectively $96.3 \%$ and $92.8 \%$. It should be noted that $63.3 \%$ had breakfast (Figure 2).

\subsubsection{Frequency of Consumption of Different Food Groups}

The food consumption of pupils was generally far from the recommendations (Figure 3). It was noted that: 7 to 8 pupils out of 10 had less than 1 serving of vegetables, fruit and dairy per day; 4 out of 10 did not have a daily ration of protein; nearly $1 / 4$ of pupils had regular weekly alcohol consumption.

\section{Discussion}

The purpose of this study was to highlight the individual behaviors of pupils in order to draw lessons for cardiovascular prevention. Collective determinants of food behavior (environmental, social, economic), not addressed in this study, should however be analyzed in a comprehensive prevention program.

The majority of pupils (90.5\%) had at least 3 meals per day. Escalon in France reported among the 12 - 30 years old, 3 meals a day for $78.8 \%$ of the respondents and 2 meals a day for $19.4 \%$ of them [8].

Taking breakfast would be associated with a lower risk of overweight among children and adolescents [9]. In our study, when reminding the last 24 hours, $63.3 \%$ of pupils reported having breakfast. Doku in Ghana reported that $31 \%$ of pupils had breakfast less than 4 days/week [10]. In the HBSC survey in France, more than half of college pupils (58.3\%) said they had breakfast every day [11]. 


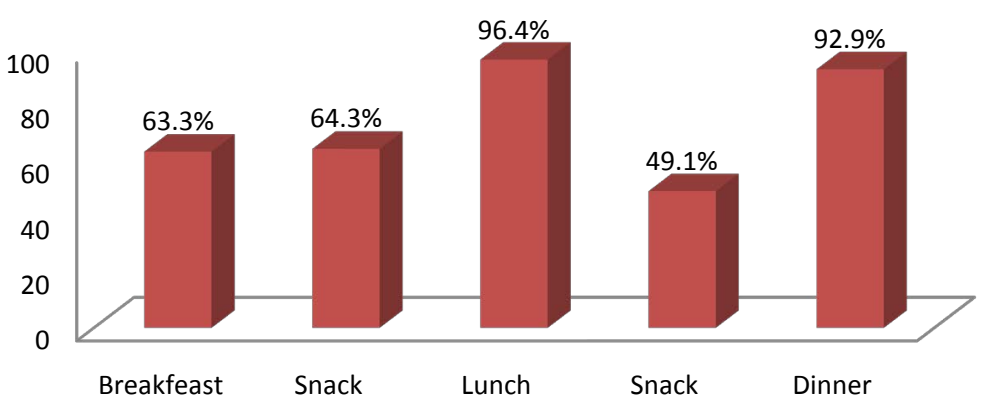

Figure 2. Participation of pupils in the different meals of the day, Bobo-Dioulasso (Burkina Faso), 2016.

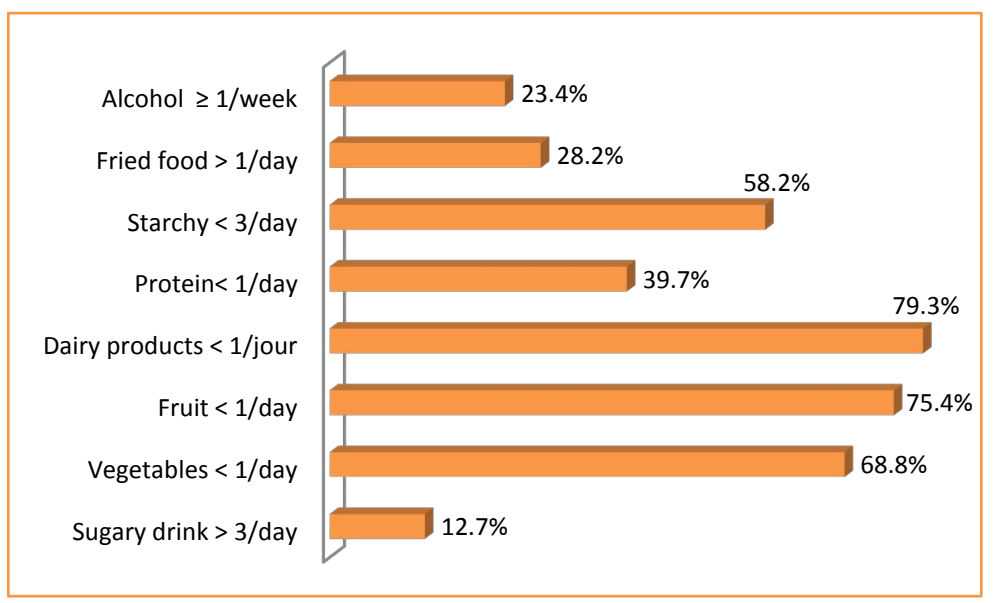

Figure 3. Frequency of pupils' consumption of different food groups, Bobo-Dioulasso (Burkina Faso), 2016.

The general consumption characteristics of the different food groups show in our study a deficiency at all the levels compared to other studies, except for the consumption of sugary drinks, which is higher among French and Algerian pupils [11] [12] (Table 1).

The consumption of dairy products was insufficient in the majority of cases (79.28\%). Yet, dairy products provide the calcium necessary for the growth of children and the strength of their bones [13]. It was the same for proteins (4 pupils out of 10), and starchy foods (6 pupils out of 10). It is not surprising in these conditions to record up to $17 \%$ of lean pupils in our schools. This poor consumption of structural foods is a reflection of the socio-economic level of our country, where $1 / 3$ of the population lives below poverty line according to the INSD [14]. In France, for example, insufficient consumption of dairy products concerned only $19 \%$ of the pupils surveyed [11]. In addition, awareness-raising interventions of the National Nutrition Health Program in schools in France could also explain our differences. We do not have for the time being a program of this type in our secondary schools and colleges.

The prevalence of alcohol consumption was $23.4 \%$. This result is higher than that of the HBSC survey in France which was 7\% [11]. WHO recommends not 
Table 1. Consumption of different food groups.

\begin{tabular}{ccccc}
\hline Consumption & $\begin{array}{c}\text { Our study } \\
(\%)\end{array}$ & $\begin{array}{c}\text { Doku } \\
\text { Ghana [10] } \\
(\%)\end{array}$ & $\begin{array}{c}\text { Allam } \\
\text { Algérie [12] } \\
(\%)\end{array}$ & $\begin{array}{c}\text { HBSC } \\
\text { France [11] } \\
(\%)\end{array}$ \\
\hline $\begin{array}{c}\text { Excessive consumption of sugary drinks } \\
\text { Insufficient vegetables }\end{array}$ & 12.7 & & 60 & 27.3 \\
$\quad$ Insufficient fruit & 90.0 & 48 & 50 & 61.2 \\
Insufficient dairy products & 75.4 & 56 & 50 & 58.9 \\
$\quad$ Insufficient protein & 39.3 & & 50 & 19.8 \\
$\quad$ Insufficient starches & 58.2 & & & \\
Excessive consumption of fried foods & 28.2 & & 15 & \\
Regular weekly alcohol consumption & 23.4 & & & 7 \\
\hline
\end{tabular}

consuming alcohol during adolescence. The actions recommended to reduce this alcohol consumption of pupils are among others, the prohibition of consumption, the increase of prices, the prohibition of sale inside and around secondary colleges [13] [15].

\section{Conclusions}

This study has revealed a general insufficiency in the recommended dietary intake of fruit, vegetables, proteins, starchy foods and dairy products among pupils; and a consumption of fatty, sugary and alcoholic foods for $1 / 10$ to $1 / 4$ of them.

The analysis of parents and guardians' food behavior, as well as the collective determinants of food behavior, would help to develop a cardiovascular prevention program adapted for this segment of the population.

\section{Aknowledgements}

UEMOA Support Program for Higher Education.

\section{References}

[1] Schroeder, S.A. (2007) We Can Do Better-Improving the Health of the American People. New England Journal of Medicine, 12, 1221-1228.

https://doi.org/10.1056/NEJMsa073350

[2] WHO (2008) Implementation of the Global Strategy on Diet, Physical Activity and Health. http://www.who.int/dietphysicalactivity/schools/en/

[3] Taylor, J.P., Evers, S. and McKenna, M. (2005) Determinants of Healthy Eating in Children and Youth. Canad Journal of Public Health, 96, S22-S29.

[4] Lino, M., Basiotis, P.P., Gerrior, S.A. and Carlson, A (2002) The Quality of Young Children's Diets. Family Economics and Nutrition Review, 14, 52-60.

[5] Wilkinson Enns, C., Mickle, S.J. and Goldman, J.D. (2002) Trends in Food and Nutrient Intakes by Children in the United States. Family Economics and Nutrition Review, 14, 56-68.

[6] Daboné Poor Nutritional Status of Schoolchildren in Urban and Peri-Urban Areas 
of Ouagadougou (Burkina Faso).

https://www.ncbi.nlm.nih.gov/pubmed/?term=Poor+nutritional+status+of+schoolc hildren+in+urban+and+peri-urban+areas+of+Ouagadougou

[7] Kouéta, F., Dao, L., Dao, F., Djekompté, S., Sawadogo, J., Diarra, Y., et al. (2011) Factors Associated with Overweight and Obesity in Children in Ouagadougou (Burkina Faso). Cahier Santé, 21, 227-231.

[8] Escalon, H. and Beck, F. (2013) Les jeunes et l'alimentation: Des comportements sexués, évoluant avec l'âge et socialement marqués. Agora débats/jeunesses, 63, 113-127. https://doi.org/10.3917/agora.063.0113

[9] Hamid, Y.H., Al Attar, F., Makhlouf, M., Ahmed, A., Jaffar, M., Dafalla, E., Mahdy, N. and Wasfy, A. (2015) A Study of Overweight and Obesity among Secondary School Students in Dubai: Prevalence and Associated Factors. International Journal of Preventive Medicine Research, 1, 153-160.

[10] Doku, D., Koivusilta, L., Raisamo, S. and Rimpelä, A. (2013) Socio-Economic Differences in Adolescents' Breakfast Eating, Fruit and Vegetable Consumption and Physical Activity in Ghana. Public Health Nutrition, 16, 864-872. https://doi.org/10.1017/S136898001100276X

[11] Dupuy, M., Escalon, H. and Jouret, B. (2010) Health Behaviour in School-Aged Children (HBSC).

http://inpes.santepubliquefrance.fr/CFESBases/catalogue/pdf/1412.pdf

[12] Allam, O., Oulamara, H. and Agli, A.N. (2016) Prevalence and Risk Factors of Overweight among School Children in a City of Eastern Algeria (Constantine). Antropo, 35, 91-102.

[13] WHO. Healthy Diet. http://www.who.int/mediacentre/factsheets/fs394/fr/

[14] National Statistics and Demographic Institute (2008) Population. Burkina Faso, 52.

[15] WHO. Alcohol. http://www.who.int/mediacentre/factsheets/fs349/en/ 